\title{
The Growth and Yield of Sweet Corn Fertilized by Dairy Cattle Effluents Without Chemical Fertilizers in Inceptisols
}

\author{
Yudi Sastro* and Indarti Puji Lestari \\ Assessment Institute for Agriculture Technology of Jakarta Jl. Raya Ragunan No. 30 \\ Pasar Minggu Jakarta Selatan (12540), Indonesia. Telp. 021-78839949 ext. 215 \\ *Correspondent author: yudis_bkl2001@yahoo.com
}

Received 1 December 2010 / accepted 2 May 2011

\begin{abstract}
Several research has proven the role of dairy cattle effluents in improving the growth and yield of some crops. However, its role in supporting the growth and yield of sweet corn, especialy in Inceptisols, has not been reported. The study aims to determine the effect of dairy cattle effluents on growth and yield of sweet corn in Inceptisols. The pot study was conducted in a greenhouse of the Assessment Institute for Agriculture Technology of Jakarta. The treatments were fertilization using dairy cattle effluents (without dilution, dilution with water 1:1 and 1:2), a mixture of Urea, SP-36 and KCl (NPK), and without fertilizer. The experimental design was a completely randomized design with five replications. Compared to a without fertilizer treatment, dairy cattle effluents were significantly increased plant height (114\%), leaf number (136\%), cob weight (131\%), cob length (124\%), and cob diameters (128\%). Base on cob weight, relative agronomic effectiveness (RAE) of dairy cattle effluents reached $38.4 \%$ (without dilution), $47.5 \%$ (dilution with water 1:1), and 62.1\% (dilution with water 1:2).
\end{abstract}

Keywords: Dairy cattle effluents, fertilizer, sweet corn

\section{INTRODUCTION}

Currently, an agriculture practice that is dependent on chemical inputs has been increasingly neglected. It is due to depletion of supporting resources, the issue of environmental pollution and global warming, and the movement of a healthy lifestyle who want the agricultural product that is free from synthetic chemicals and is produced through healthy farming practices as well as friendly to the environment (Agric Notes 2002; Surono 2004; Sutanto 2004; Bio Cert 2006).

One of strategy to be done by the society in carrying those issues is through the use of dairy cattle effluents as fertilizer. Dairy cattle effluents is a mixture of cattle urine and leachate from cages and faeces. Based on the volume and nutrient content, the dairy cattle effluents is more potential than its solid waste (Wesolowski 1999). Matsi et al. (2003) reported that the nutrient content of dairy cattle effluents reached $0.3-0.6 \% \mathrm{~N} ; 0.04$ to $0.08 \%$ $\mathrm{P}$, and 0.5 to $0.8 \% \mathrm{~K}$. Zhang et al. (2006), Lithourgidis et al. (2007), Parsons et al. (2007), and Dordas et al. (2007) have been reported the significant effect of dairy cattle effluents combined

J Trop Soils, Vol. 16, No. 2, 2011: 139-143

ISSN 0852-257X with chemical fertilizer on the growth and yield of wheat, soybeans, and forage.

However, testing of dairy cattle effluents on crops without chemical fertilizers has not been reported. Therefore, it is still need to conduct the study in order to maximize the benefits of animal waste as fertilizer that can support the development of agricultural.

This research aimed to study the role of dairy cattle effluents in supporting the growth and yield of sweet corn without chemical fertilizers in Inceptisols.

\section{MATERIALS AND METHODS}

\section{Soil Samples}

Top soil samples ( $0-15 \mathrm{~cm}$ depth) of Inceptisols were taken from Cipedak, Jagakarsa, South Jakarta (BBSDL 2007). The soil samples were air-dried, crushed and sieved through a $2 \mathrm{~mm}$ sieve. The samples were analyzed in the laboratory using the procedures as described in Puslitanak (1998). Characteristics of soil that analyzed were $\mathrm{pH}\left(\mathrm{H}_{2} \mathrm{O}\right)$ 5.9 , organic-C $1.47 \%$, total- $\mathrm{N} 2.5 \%$, available-P 930 mg kg-1 of $\mathrm{P}_{2} \mathrm{O}_{5}, \mathrm{~K} 90 \mathrm{mg} \mathrm{kg}^{-1}$ of $\mathrm{K}_{2} \mathrm{O}$, CEC 25.3 cmol kg-1 and soil fractionation was $2 \%$ sand, $23 \%$ silt, and $75 \%$ clay. 


\section{Dairy Cattle Effluents}

The dairy cattle effluents prepared by aerobic fermentation using an aerobic fermentor. As much as 90 liters of effluents were mixed with 10 liters of molasses entered into the fermentor and stirred until homogenous using stirrer machine. Furthermore, the material was inoculated using microbial culture (EM-4) as much as $1.000 \mathrm{ml}$ and fermented for three weeks. Fermentation was ended when the smell of waste to be like beer and the formation of foam on the surface. Characteristic of dairy cattle effluents were $\mathrm{pH} 6.2$, carbon $318 \mathrm{mg} \mathrm{l}^{-1}$; total nitrogen $60 \mathrm{mg} \mathrm{l}^{-1}$, phosphorus $4 \mathrm{mg} \mathrm{l}^{-1}$, and potassium $700 \mathrm{mg} \mathrm{l}^{-1}$.

\section{Plant Testing}

Plant testing was conducted in a greenhouse using plastic pots containing $5 \mathrm{~kg}$ of soil samples. The experiment was arranged using a Completely Randomized Design (CRD) with five replicates. Treatments were: (1) without fertilization as control; (2) dairy cattle effluents without diluted with water; (3) dairy cattle effluents diluted with water $1: 1$; (4) dairy cattle effluents diluted with water 1:2; and (5) inorganic fertilizer i.e. a mixture of urea (2 g), TSP $(2 \mathrm{~g})$, and $\mathrm{KCl}(2 \mathrm{~g})$ that was dissolved in a litter of water.

Each pot was planted with sweet corn as much as three seeds per pot. Reduction of plant performed was done at seven days after transplanting (DAT) by leaving one plant per pot. Fertilizer application was done by pouring a 100 $\mathrm{ml}$ of fertilizer solution per pot per week until the harvest. Measurements of plant height and number of leaves were done since seven days after transplanting until maximum vegetative growth. Crop yield variables (length, diameter, and cob weight) were measured at harvest.

\section{Data Analysis}

Data were analyzed by using analysis of variance (ANOVA). Differences between treatments were tested by using Duncan's Multiple Range Test (DMRT) at 5\% test level (Gomez and Gomez 1984). Fertilizer effectiveness was determined based on the value of relative agronomic effectiveness (RAE) (Bolan et al. 1990; Purnomo 1992):

$$
\mathrm{RAE}=\frac{\mathrm{Ya}-\mathrm{Yc}}{\mathrm{Yb}-\mathrm{Yc}} \times 100 \%
$$

Ya = dairy cattle effluents fertilizer yield

$\mathrm{Yb}=$ NPK fertilizer yield

$\mathrm{Yc}=$ control without fertilizer yield

\section{RESULTS AND DISCUSSION}

Based on statistical analysis, the height of maize at each fertilizer treatment of dairy cattle effluents at each observation weeks was significantly higher than the unfertilized treatment. However, plant height at each dairy cattle effluents were significantly lower than the NPK treatment. There was a tendency of increasing in plant height due to decreasing concentration of dairy cattle effluents, especially since 21 days after transplanting (DAT) (Table 1).

Leaf number of corn that fertilized using dairy cattle effluents at each dilution level (DCE-1, DCE2 , and DCE-3) were significantly more than the unfertilized treatment. The number of leaves at the dairy cattle effluents were not significantly different with NPK. However, based on the mean value, number of leaves on the NPK treatment at each week of observation were more than the dairy cattle effluents treatments. At the end of the observation, there was a tendency of rising in the number of leaves along with the decline in concentration of dairy cattle effluents (Table 2).

Table 1. Effect of dairy cattle effluents on plant height of sweet corn.

\begin{tabular}{lccrrr}
\hline \multirow{2}{*}{ Treatments } & \multicolumn{5}{c}{ Plant height $(\mathrm{cm})$} \\
\cline { 2 - 6 } & $14 \mathrm{DAT}$ & $21 \mathrm{DAT}$ & $28 \mathrm{DAT}$ & $35 \mathrm{DAT}$ & $42 \mathrm{DAT}$ \\
\hline Without fertilizer & $42.2 \mathrm{a}$ & $63.7 \mathrm{a}$ & $98.8 \mathrm{a}$ & $125.7 \mathrm{a}$ & $146.9 \mathrm{a}$ \\
DCE-1 & $48.0 \mathrm{~b}$ & $69.7 \mathrm{~b}$ & $105.3 \mathrm{~b}$ & $137.6 \mathrm{~b}$ & $160.7 \mathrm{~b}$ \\
DCE-2 & $48.4 \mathrm{~b}$ & $70.7 \mathrm{~b}$ & $104.9 \mathrm{~b}$ & $139.3 \mathrm{~b}$ & $163.1 \mathrm{~b}$ \\
DCE-3 & $48.4 \mathrm{~b}$ & $75.4 \mathrm{bc}$ & $108.4 \mathrm{~b}$ & $143.4 \mathrm{~b}$ & $167.4 \mathrm{~b}$ \\
NPK & $49.3 \mathrm{~b}$ & $78.1 \mathrm{c}$ & $118.8 \mathrm{c}$ & $157.6 \mathrm{c}$ & $176.7 \mathrm{c}$ \\
\hline
\end{tabular}

Note: The numbers followed by the same letter at same row were not significantly different according to DMRT 5\%; DAT = days after transplanting; DCE-1 = dairy cattle effluents without dilution; DCE-2 = dilution with water $1: 1 ;$ DCE-3 = dilution with water $1: 2$. 
Table 2. Effect of dairy cattle effluents on leaf number of sweet corn.

\begin{tabular}{lcccrc}
\hline \multirow{2}{*}{ Treatments } & \multicolumn{5}{c}{ Leaf number } \\
\cline { 2 - 6 } & $14 \mathrm{DAT}$ & $21 \mathrm{DAT}$ & $28 \mathrm{DAT}$ & $35 \mathrm{DAT}$ & $42 \mathrm{DAT}$ \\
\hline Without fertilizer & $4.1 \mathrm{a}$ & $6.2 \mathrm{a}$ & $8.1 \mathrm{a}$ & $9.4 \mathrm{a}$ & $10.0 \mathrm{a}$ \\
DCE-1 & $5.2 \mathrm{~b}$ & $7.2 \mathrm{~b}$ & $8.8 \mathrm{~b}$ & $10.6 \mathrm{~b}$ & $12.4 \mathrm{~b}$ \\
DCE-2 & $5.2 \mathrm{~b}$ & $7.2 \mathrm{~b}$ & $9.2 \mathrm{~b}$ & $10.6 \mathrm{~b}$ & $12.8 \mathrm{~b}$ \\
DCE-3 & $5.0 \mathrm{~b}$ & $7.0 \mathrm{~b}$ & $8.8 \mathrm{~b}$ & $10.8 \mathrm{~b}$ & $13.6 \mathrm{~b}$ \\
NPK & $5.4 \mathrm{~b}$ & $7.2 \mathrm{~b}$ & $9.2 \mathrm{~b}$ & $11.2 \mathrm{~b}$ & $14.2 \mathrm{~b}$ \\
\hline
\end{tabular}

Note: The numbers followed by the same letter at same row were not significantly different according to DMRT 5\%; DAT = days after transplanting; DCE-1 = dairy cattle effluents without dilution; DCE$2=$ dilution with water $1: 1 ;$ DCE-3 = dilution with water $1: 2$

Table 3. Effect of dairy cattle effluents on sweet corn yield.

\begin{tabular}{lccc}
\hline Treatments & Cob length $(\mathrm{cm})$ & Cob diameter $(\mathrm{cm})$ & Cob weight $(\mathrm{g})$ \\
\hline Without fertilizer & $9.5 \mathrm{a}$ & $27.6 \mathrm{a}$ & $39.2 \mathrm{a}$ \\
DCE-1 & $11.3 \mathrm{~b}$ & $33.7 \mathrm{~b}$ & $46.8 \mathrm{~b}$ \\
DCE-2 & $11.6 \mathrm{~b}$ & $35.0 \mathrm{~b}$ & $48.6 \mathrm{~b}$ \\
DCE-3 & $11.8 \mathrm{~b}$ & $35.3 \mathrm{~b}$ & $51.5 \mathrm{~b}$ \\
NPK & $15.4 \mathrm{c}$ & $39.3 \mathrm{c}$ & $59.0 \mathrm{c}$ \\
\hline
\end{tabular}

Note: The numbers followed by the same letter at same row were not significantly different according to DMRT 5\%; DAT = days after transplanting; DCE-1 = dairy cattle effluents without dilution; DCE-2 = dilution with water 1:1; DCE-3 = dilution with water 1:2.

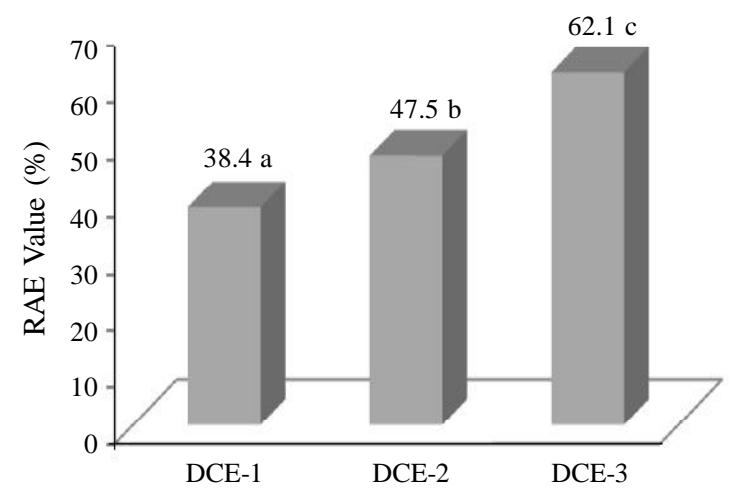

Figure 1. Relative agronomic effectiveness value (RAE) of dairy cattle effluents fertilizer based on cob weight.

The length, diameter, and weight of sweet corn cobs on each liquid waste fertilizer treatments (DCE-1, DCE-2, and DCE-3) were significantly higher than the unfertilized treatment. However, the cob corn size at dairy cattle effluents fertilizers were significantly lower than NPK fertilizer. There was a tendency of increasing the size of cobs that due to decreasing of dairy cattle effluents concentration (Table 3).

Based on cob weight, relative agronomic effectiveness (RAE) value of dairy cattle effluents were $38.38 \%$ (DCE-1), $47.47 \%$ (DCE-2), and
$62.12 \%$ (DCE- 3), respectively. In line with other observed variables, there was an increase in the RAE value in line with the increase of dilution level of dairy cattle effluents. There was a tendency of increasing in RAE value along with the increase of the dairy cattle effluents dilution level (Figure 1).

The low of RAE value on dairy cattle effluents treatments were caused by the low of nutrient supply, especially N, P and K. The NPK fertilizer used in this study was mixtures of urea, SP36, and $\mathrm{KCl}$ that contained $45 \% \mathrm{~N}, 36 \% \mathrm{P}_{2} \mathrm{O}_{5}$, and $45 \%$ $\mathrm{K}_{2} \mathrm{O}$, respectively. While, the concentration of $\mathrm{N}$, $\mathrm{P}$, and $\mathrm{K}$ in dairy cattle effluent was low, as presented in materials and methods. Total N, P, and $\mathrm{K}$ applied per pot in each treatment is presented in Table 4. Differences in nutrient supply were thought to cause the differences in plant growth rate and yield as reported by Kumar et al. (2007); Yusuff et al. (2007), and Orosz et al. (2009).

Meanwhile, the trends of increased growth and yield with increasing dilution of dairy cattle effluents can not be explained certaintly yet. If based on a mathematical calculation, dilution of the dairy cattle effluents fertilizer will reduce the supply of nutrients to the soil (Table 4). Presumably there were other factors that become the cause, including organic and inorganic compounds contained in liquid waste, especially phenol compounds (Miller 
Table 4. Total of N, P, and $\mathrm{K}$ applied per pot in each treatment.

\begin{tabular}{lccc}
\hline Treatments & $\begin{array}{c}\mathrm{N} \\
\left(\mathrm{mg} \mathrm{pot}^{-1}\right)\end{array}$ & $\begin{array}{c}\mathrm{P} \\
\left(\mathrm{mg} \mathrm{pot}^{-1}\right)\end{array}$ & $\begin{array}{c}\mathrm{K} \\
\left(\mathrm{mg} \mathrm{pot}^{-1}\right)\end{array}$ \\
\hline DCE-1 & 9 & 6 & 105 \\
DCE-2 & 45 & 3 & 52.5 \\
DCE-3 & 30 & 2 & 35 \\
NPK & 405 & 324 & 414 \\
\hline
\end{tabular}

and Varel 2002; Koloziej et al. 2004; Wilkie et al. 2004; Ciganek and Neca 2008; Watkins and Nash 2010). Phenol compounds were reported to inhibit the growth of several crops as reported by Aranda et al. (2006); Canakci (2008); Haddadchi and Gerivani (2009); and Canakci and Munzuroglu (2009). In addition, there were also suspected to be anti-odour inorganic compounds, including chlorine and potassium permanganate that was usually used in the cattle farm wastewater (Miner 1977). This conjecture was reinforced by the high content of $\mathrm{K}$ in the wastewater as shown in Materials and Method.

\section{CONCLUSIONS}

Value of relative agronomic effectiveness (RAE) of dairy cattle effluent reached $62.1 \%$. The RAE value was relatively small, however it has indicated that dairy cattle effluent fertilizer can be used as a source of nutrients for sweet corn plant in Inceptisols, especially in organic cropping systems without chemical fertilizers. Relative agronomic effectiveness of these fertilizers can be improved through increased nutrient content, such as enrichment treatment using mineral and organic substance during fermentation or by increasing the intensity of fertilization.

\section{REFERENCES}

Agriculture Notes. 2002. Organic Farming. Farm diversification service and Sue Titcumb.

Aranda A, I Samedro, JA Ocampo and I Garcia-Romera. 2006. Phenolic removal of olive-mill dry residues by laccase activity of white-rot fungi and its impact on tomato plant growth. Int Biodet Biodeg 58: 176-179.

BBSDL [Balai Besar Litbang Sumberdaya Lahan Pertanian]. 2007. Identifikasi dan Evaluasi Potensi Lahan Untuk Mendukung Prima Tani di Kelurahan Cipedak, Srengseng Sawah, dan Ciganjur, Kecamatan Jagakarsa-Kota Jakarta Selatan. Balai Besar Sumber Daya Lahan, Bogor (in Indonesian).
Bio Cert. 2006. Rp 30 Milyar untuk pengembangan program pertanian organik. www.biocert.or.id. Newsletter Trust In Organic. Edisi 4 tahun 1, NovDes.

Bolan NS, RE White and MS Hedley. 1990. A review of the use of phosphate rock as fertilizers for direct application in Australia and New Zaeland. Aust $J$ Exp Agric 30: 297-313.

Canakci S. 2008. Effects of salicylic acid on fresh weight change, chlorophyll and protein amounts of radish (Rhapanus sativus L.) seedling. J Biol Sci 8 (2): 431-435.

Canakci S and O Monzuroglu. 2009. Effects of salicylic acid on growth and chlorophyll destruction of some plant tissue. Word J Agric Sci 5 (5): 577-581.

Ciganek M and J Neca. 2008. Chemical characterization of volatile organic compounds on animal farms. Vet Med 53: 641-651.

Dordas CA, AS Lithourgidis, T Matsi and N Barbayiannis. 2007. Application of liquid cattle manure and inorganic fertilizers affect dry matter, nitrogen accumulation, and partitioning in maize. Nut Cyc Agroec J 80: 283-296.

Gomez KA and AA Gomez. 1984. Statistical Procedures for Agricultural Research. John Willey and Sons, New York.

Haddadchi GR and Z Gerivani. 2009. Effects of phenolic extract of canola (Brassica napuse L.) on germination and physiological responses of soybean (Glycine max L.) seedling. Int J Plant Prod 3 (1): 63-74.

Kumar MAA, SK Galli and RV Patil. 2007. Effect of level of NPK on quality of sweet corn grown on vertisols. J Agric Sci 20: 44-46.

Kolodziej EP, T Arter and DL Sedlak. 2004. Dairy wastewater, aquaculture, spawning fish as sources of steroid hormones in the aquatic environment. Environ Sci Technol 38: 6377-6384.

Lithourgidis AS, T Matsi, N Barbayiannis and CA Dordas. 2007. Effect of liquid cattle manure on corn yield, composition, and soil properties. Agron J 99: 1041-1047.

Matsi T, AS Lithourgidis and AA Gagianas. 2003. Effects of injected liquid cattle manure on growth and soils characteristics. Agron J 95: 592-596.

Miller DN and VH Varel. 2002. In vitro study of the biochemical origin and production limits of odorous compounds in cattle feedlots. J Anim Sci 80: 22142222.

Miner JR. 1977. Characterization of odors and other volatile emissions. Agric and Environ 3 (2-3): 129137.

Orosz F, S Jakab, T Losak and K Slezak. 2009. Effects of fertilizer application to sweet corn (Zea mays.) grown on sandy soil. J Environ Biol 30 (6) : 933-938.

Parsons KJ, VD Zheljazkov, J MacLeod and CD Caldwell. 2007. Soil and tissue phosphorus, potassium, cadmium, and sulfur as affected by dairy manure application in a no-till corn, wheat, and soybean rotation. Agron J 99: 1306-1316. 
Purnomo E. 1992. Management of Phosphorus Fertilizers in Soil with an Acid Subsurface Layer. MAppSc. Thesis, CSU Wagga New South Wales, Australia.

Puslitanak. 1998. Penuntun Analisa Kimia Tanah dan Tanaman. Pusat Penelitian Tanah dan Agroklimat. Bogor (in Indonesian).

Surono I. 2004. Pertanian organik Indonesia dalam Jurnal Berita Bumi. Edisi Juli 2004 (in Indonesian).

Sutanto R. 2003. Pertanian Organik Menuju Pertanian Alternatif dan Berkelanjutan. Kanisius Yogyakarta (in Indonesian).

Watkins M and D Nash. 2010. Dairy factory waste water, their use on land and possible environmental impact-a mini review. Open Agric J 4: 1-9.
Wesolowski P. 1999. Use of liquid manure on permanent grasslands. Agrochem J 10: 20-21.

Wilkie AC, HF Castro, KR Cubinks, JM Owens and SC Yan. 2004. Fixed-film anaerobik digetion of flushed dairy manure after primary treatment: wastewater production and characterisation. $\mathrm{J} \mathrm{Biol}$ Eng 89 (4): 457-471.

Yusuff MTM, OH Ahmed, WAW Yahya and NMA Majid. 2007. Effect of organic and anorganic fertilizers on Nitrogen and Potassium uptake and yield of sweet corn on an acid soil. Am J Agric Biol Sci 2 (2):118-112.

Zhang M, R Gavlak, A Mitchell and S Sparrow. 2006. Solid and liquid cattle manure application in a subarctic soil. Agron J 98: 1551-1558. 